\title{
Global Is Local: Recycling Familiar Components
}

\author{
Rolf Solli \\ University of Gothenburg. Sweden \\ Peter Demediuk \\ Victoria University, Australia
}

\begin{abstract}
We have observed that management strategies change places and sometimes proceed in the opposite direction in different locations. At the same time, all ideas appear to be represented throughout many organisations. We claim that what are normally referred to as global ideas actually represent the local recycling of old ideas. Management strategies change names, speed and are combined in different ways and global trends function as catalysts. This study, which has been carried out for over ten years, summarises our experiences from a comparative study of the development of reforms in Australian and Swedish municipalities.
\end{abstract}

\section{Keywords}

Australian and Swedish municipalities, global ideas, local ideas

\section{Prologue}

Shortly after one author of this article had received his Ph.D., he came across Geert Hofstede's book "Cultures and Organizations: Software of the Mind" (Hofstede 1991). At that time the book was to become one real 'bestseller' and a point of departure for the creation of alternative frameworks (see for example Trompenaars and Hampden-Turner 2005) and large scale international research projects such as GLOBE (Global Leadership and Organizational Behavior Effectiveness). The book inspired him to study the ways in which multinational organisations manage their various branches in different countries. He had finally found an idea for a research project to replace his dissertation! He and a colleague subsequently conducted a test interview at one of Sweden's multinational corporations. This corporation carries out business operations throughout the entire world. There probably isn't a single country that does not have products made by this particular corporation. The researchers met with the corporation's finance director. His answer to the question regarding the ways in which the corporation adapted its management strategies in countries with different cultures was simply: "We don't adapt. The culture of the corporation is what counts". That was it. That director of finance probably realised that he had ruined our great idea and offered us a tour of the factory which was adjacent to the corporate headquarters. While the tour was interesting the factory appeared as expected. There were people and machines in continuous movement.

Copyright (C) 2008 Victoria University. This document has been published as part of the Journal of Business Systems, Governance and Ethics in both online and print formats. Educational and non-profit institutions are granted a nonexclusive licence to utilise this document in whole or in part for personal or classroom use without fee, provided that correct attribution and citation are made and this copyright statement is reproduced. Any other usage is prohibited without the express permission of the
Nearly twenty years later the same researchers found themselves in India and happened to visit one of the corporation's factories there. The factory actually looked the same as the one we had seen in Sweden, or at least the way we remembered it. The finance director might actually have been right. Or maybe it had taken a while for management initiatives to reach their target. Luckily, the researchers had continued to 
carry out research of the main idea from a different perspective.

\section{Ideas are Up Over and Down Under}

Ideas travel quickly; there are many examples of copied ideas that were actually implemented before the original (Solli, et al. 2005). Management ideas in particular appear to spread quickly (Olson, et al. 1998). Reforms appear to be a necessary characteristic of modern organisations in many ways. Organisations seem to depend on demonstrating that they are capable of adapting to their environment (DiMaggio 1983) and are sometimes even able to demonstrate their ability to affect it. Efficiency is often the most important argument, because it almost automatically provides legitimacy (Brunsson 2000). Democracy is a good argument as well with regard to organisations that are managed by political entities although democracy will usually take second place when competing with efficiency (Jönsson, et al. 1995).

Organisations tend to operate in environments that contain many other organisations which might explain why organisational structures tend to become more and more similar. Walter Powell and Paul DiMaggio (Powell and DiMaggio 1991) call this phenomenon 'isomorphism' which has been followed by several other Greek concepts. 'Isopractice' is used to describe similar practices, 'automorphism' for imitating the past (Schwarz 1997) and 'isonymism' for borrowing names. Why not use the term allonymism to describe the desire to borrow everything but the name (Solli, Demediuk and Sims 2005)? Another explanation for these increased similarities might be that there is a constant demand for new ideas, which might give new life to ideas that have not been used for a long time. The latter phenomenon represents one of the questions that we will address in this paper. We will therefore begin by assuming that there is a demand for ideas that might provide a foundation for the actions and rhetorical exercises we typically refer to as reforms. We wonder where these ideas might be coming from.

One important question in this context is what ideas individuals and organisations develop as their own. Long ago, Gabriel Tarde (1890/1962) asked which idea might become most popular among all the ideas that are continuously present. The answer was that the new idea has to be superior to the other ideas. The subsequent crucial question is who determines the superiority. Even during Tarde's time the answer highlights the importance of media. He identified three different reasons for why an idea might be superior. First, the idea has to be "logically superior": it has to appear more reasonable than others. Second, ideas that come from "fashion centers" - the royal court in old times or large cities in modern times (Czarniawska and Solli 2001) - are usually determined superior. Third, the new idea should not collide with ideas that are already institutionalised, but should instead be supported by at least a few of them ("... the old Greeks already..."). Tarde, however, made a clear distinction between propagating old ideas, to which he referred to as imitating habit, and new ideas which he called imitating fashion. Unlike many of today's sociologists, fashion was a central concept to Tarde. This central idea was picked up by Czarniawska (Czarniawska 2005; Czarniawska and Joerges 1995) who demonstrate the ways in which fashion constitutes a precondition as well as an explanation for why certain ideas are accepted.

\section{Methodology}

We have followed efforts to reform the public sector both in Sweden and in Australia for a long time (Solli 1988; Solli, et al. 2000; Solli, Demediuk and Sims 2005). By comparing Australia to Sweden we tried to distinguish a pattern regarding the ways in which reforms occur in organisations as well as the ways in which old ideas are reused and minor ideas become major ideas.

Our different country of origin represented a crucial methodological resource for our project. Foreigners are generally able to ask any questions while native-born individuals are better at detecting when people are talking nonsense. This project combines these two advantages as one of us is a foreigner in Sweden and one in Australia. The same holds true for the native-born perspective as well. In both cases, the foreigner consistently has had the main responsibility for conducting the interviews while the nativeborn asked the more aggressive questions when needed. The interviews were conducted in both countries 
approximately every other year since 1995. In all, over 100 interviews were conducted and were based on the following question: How is your municipality managed? We primarily interviewed financial directors and directors of municipal operations. However, we also interviewed politicians and operations managers. Each round of interviews included at least one national organisation that might have overseen reforms.

We visited our field of study, the municipalities in Sweden and in the State of Victoria in Australia. In 2007 alone, we visited nine municipalities in Victoria as well as two organisations above the municipal level and we conducted interviews with 32 individuals. In Sweden, we visited four municipalities, three central organisations and interviewed 11 individuals.

The selection of municipalities was based primarily on their reputation for being interesting while others were selected almost randomly. We visited same municipalities on several occasions: two in Victoria and one in Sweden. Two organisations above the municipal levels in Australia and one in Sweden were visited by us consistently over time. Our strategy included combining proximity with distance. Interviewees from the municipalities were able to describe the ways in which things are done locally whereas those at the level above municipalities might discuss municipalities in general. The former usually concern ongoing processes while the latter tends to focus more on institutional organisations in general (Barley and Tolbert 1997). All interviews, including those in Sweden, were conducted in English. It might have been advantageous to conduct the Australian interviews in Swedish, but we unfortunately did not have that option. As a result, we made an unexpected, but interesting methodological observation. Interviews in a foreign language tend to be less filled with current popular vocabulary. Interviewees instead attempted to speak more directly.

In addition to the interviews we have continued to monitor events throughout municipalities and through newspapers and other research projects that highlight the current "management trend". As a result we have compiled a lot of relevant data.

Our open questions force us to use qualitative methods. We are looking for what practice local governments use - without knowing what sort of answer we will get. The data we obtain are first transcribed to ordinary text and then codified and analysed according our frame of reference, here we call that "our filters". This open minded method is necessary when practice is studied (Latour 1994). We treat the risk of capricious interpretation by confrontation. The subjects interviewed, or people in similar positions, are reading or listening our text and can react if the descriptions are out of order.

\section{Our Filters}

Our series of interviews -5 or 10 depending on how you count - were explorative. Our primary question on every occasion was: "How is your municipality managed?". Occasionally we included a sub-question of particular interest. One example includes a study of the role of the director of finance (Solli, Demediuk and Sims 2000). Otherwise, we allowed the respondents to describe their situation and, based on their responses, we asked follow-up questions or for more details as needed. This does not mean, however, that we did not have any preconditions for either data collection or analysis. Like everyone else, we use a number of filters, or frames of reference, as a response to what other individuals show and tell us. In part, this concerns how the field is constructed and the understanding with which it is associated. It also depends on how we viewed the stories and images that we encountered.

Our research thus focused on the management tools that municipalities use and the ways in which they change. This means that we implicitly categorised the data from the interviews according to a hypothetical guideline or a particular logic. Our point of view is based on what some might call 'Public Management'. Our primary references include books such as "Budgeting" by Aaron Wildavsky (Wildavsky 1975); "Making Budgets" by James Danziger (Danziger 1978); Herman van Gunsteren's "The Quest for Control" (Gunsteren 1976) and Sten Jönsson's "City Administration Facing Stagnation" (Jönsson 1982). This literature not only describes the past, but surprisingly often it is also applicable to today's conditions. The aforementioned books primarily examined the culture of planning and 
bureaucracy. These "classic" studies were carried out long before what is currently referred to as "New Public Management'. Although many authors have written about the subject according to SahlinAndersson (2001) the term appears to originate from Christopher Hood (Hood 1991). Whilst we are not aware of any municipality that has called its reforms NPM, nevertheless, reforms from the 1980s-1990s contain many of its components including increased privatisation, more business-like organisational structures, competition and other aspects which view the market as a good force in society. The question is: What will come after the NPM? The development trends indicate that it will be a different theory altogether. We agree with Henry Mintzberg's belief that we understand strategies only when we know what happened (Mintzberg 1978, 1994 and see also Whittington 2004) and we continue to look.

Our second filter is related to how we view what we have seen or heard. It is based on the idea that it is actually impossible for individuals to describe exactly what they are doing and why. Barbara Czarniawska (Czarniawska 2001) provides one explanation for this phenomenon. Her explanation, based partly on Pierre Bourdieu (Bourdieu 1990), distinguishes between three different kinds of logic: theory, practice and representation. The ability of practical logic to explain a particular situation falls within the framework of representative logic or occasionally within the logic of theory. To the extent that this constitutes a problem, there are several solutions. We preferred a solution that involved turning the interviews into a dialogue between the interviewer and the interviewee. A theory was thus developed through the interaction (Kreiner and Mouritsen 2005).

In our frame of analysis the difference between representative and practical logic is closely connected to the concept of translation (Callon 1986; Latour 1986). For example, organisation A employs a practice that is introduced through a representative story. Someone in organisation B reads the story and encourages others to share. After various detours, A's story is adapted so that it can also be practiced in organisation B. Every step involves a change. Therefore, A and B may not actually be doing the same things in practice. While the results might be similar, there may be many differences.

\section{Contextual Differences}

Even a fairly superficial assessment reveals significant differences between the immediate contexts of Swedish and Australian municipalities. In Sweden, the same laws apply to all municipalities. Australia, on the other hand, is a federation, which results in large differences between a municipality in the state of New South Wales and one in the state of Victoria. These differences make it difficult to determine the number of municipalities. A qualified guess estimates that there are between 675 and 775 (Gerritsen and Whyard 1998). The Swedish constitution protects municipal independence and the national government thus has less influence than in Australia. In Victoria most decisions regarding municipal independence are made at the state level. In 2007 there were 79 municipalities in Victoria compared with 285 in Sweden. The state has extensive influence. For example, the premier (the state's prime minister) has the power to dismiss the municipal government if he or she believes that they have made unwise decisions.

There are significant differences between operations. A relatively ordinary Swedish municipality has approximately 30,000 residents and spends about 40,000 SEK per resident. An average municipality in Victoria has approximately 55,000 residents and spends about 6,000 SEK/resident. The main difference concerns the municipalities' responsibilities. The largest expenditures in Victorian municipalities are related to infrastructure, or more specifically, to maintaining the road system. While Australian municipalities are also responsible for some so-called "soft" operations, these may be considered marginal compared to Swedish municipalities. Swedish municipal operations primarily include education and social services which in Australia are primarily the state's responsibility.

Political work in the two countries takes place under completely different conditions. Australia has almost no full-time politicians at the municipal level while every Swedish municipality employs two or more full-time politicians. 


\section{Australia: Victoria}

\section{The Kennett Revolution}

We have many reasons for starting our study in 1992 and concluding it in 2007. In 1992, the Liberals and National Party coalition won the Victorian election replacing the Labor Party. As the leader of the Liberal Party Jeff Kennett was elected Premier. The winners had been fairly certain of their victory and had not made many specific election promises. At the time of the election, Victoria was experiencing considerable financial trouble which resulted in the winners' strong self confidence. Kennett immediately launched significant reforms which eventually became one of the programs that was most inspired by New Public Management. At first, it primarily focused on getting the economy back on track. Privatisation was a significant aspect of the reforms. In addition, a radical merger of municipalities was implemented. All municipal governments were dismissed and were replaced by state appointed public officials. The number of municipalities was reduced from 210 to 78 . It is important to note that municipal mergers had not been discussed at all prior to the election and did not cause any significant protests (Costar and Economou 1999). Each new municipality had to reduce costs by $20 \%$. In addition, at least $50 \%$ of overall operations were to be open to competition, known as compulsory competitive tendering (CCT). Municipal management techniques were often converted into a more business-like approach. For example, financial directors were often recruited from the private sector based on the assumption that accounting was the same in the private and public sectors (Olson, Guthrie and Humphrey 1998; Solli, Demediuk and Sims 2000).

Jeff Kennett himself labeled the reform efforts the Kennett Revolution (Parkinson 2000). However, although the changes were significant, whether they constituted a revolution or an adaptation might be open to debate (Costar and Economou 1999). Although the outcome of any particular policy is the result of many factors, the goals were reached fairly quickly.

Prior to the state elections in 1999 the Labor Party sharply criticised the reforms of the Kennett government, primarily regarding the aspects related to CCT. While CCT had clearly resulted in lower costs and a reasonable quality in some cases, there were many examples of the opposite (Sims 2000). Interest groups, including Local Government Professionals consisted of high ranking officials in the municipalities who put firm pressure on the Labor Party to oppose CCT. The Labor Party did just that in 1999 and, to the surprise of many, won the election and the Bracks' government took office.

\section{Best Value Victoria}

One of the first things the Bracks government did after taking office was to replace the legislation that addressed CCT. They merely replaced it with a new section: the Local Government Act 2:6, which introduced the concept Best Value. The new law took effect on January 1, 2000.

The new law was based on six principles which may be summarised in the following key points:

1. All services must meet quality and cost standards.

2. All services must be responsive to the needs of the community.

3. A service must be accessible to those for whom it is intended.

4. A council must achieve continuous improvement of its provision of services.

5. A council must regularly consult with the community about services.

6. A council must report regularly, at least yearly, on its achievements to its community in relation to the Best Value Principles.

Opinions differ regarding how Best Value Victoria (BVV) came to exist. One story involves a visit to England by the director of municipal operations of Melbourne City in 1998. Back in Australia he decided that Best Value should be implemented in Melbourne City and be adapted to local conditions. A couple of the important ingredients of the English version were removed prior to the municipality supporting the initiative. For example, the inspection/audit system was not natural. This obviously also 
includes the key metrics/performance indicators, which are mandatory in England and on which comparisons with other municipalities are based. It was, however, possible to translate the idea of consulting users and creating voluntary comparisons such as benchmarking.

In addition to the name there are other significant differences from the English "original". There are no inspections, no key numbers on which to base comparisons and definitely no significant publications on the web. The Australian version, however, also has different objectives. Municipalities had become anonymous during the reforms of the 1990s. In addition, municipalities did not enjoy a high degree of legitimacy in the eyes of residents (Solli, Demediuk and Sims 2000). The anonymity was due in part to the mergers and partly to the Kennett government's very direct management of the municipalities. The new law stipulated that operations should be reviewed. These reviews were viewed as a way to make operations more functional, and to make the municipalities more transparent to their residents. By asking residents a series of questions they were expected to become more interested in municipal operations.

Politicians and career officials generally believed that BVV was actually just a matter of "good management". The trick, however, was to introduce evaluations into regular management. The idea was that operations as well as quality would improve if they were evaluated by consulting users and residents and compared with other municipalities.

While there are examples of some improvement, the general opinion is that the reforms never took off. Evaluation practices were implemented in operations that had never been exposed to outside competition (CCT) which varied between municipalities. It is also important to note that according to law, all operations were to be evaluated over a five year period.

In summary, BVV focused on local issues with an emphasis on evaluations which were expected to result in better services for residents. BVV key words included: transparency, improvements, decentralisation and not the least, building identity. The reforms in Victoria have the same name and are, to some extent, inspired by the English version. However, a comparison between England and Victoria reveals that the differences outnumber the similarities both with regard to practices and the ways in which concepts are described.

An insider claimed that comparing the Kennett revolution to Victoria's version of Best Value is like comparing the Hiroshima nuclear bomb with aromatherapy. This metaphor probably underestimates the powers of both the Hiroshima bomb and aromatherapy. Reports from the Best Value Commission still show results, but it is difficult to determine whether the results would have happened anyway.

\section{Community Engagement and Participant Budgeting}

In the round of interviews from early 2007, BVV was not portrayed as something dramatic, but appeared to be taken for granted. The respondents tended to emphasise other activities with community engagement being a particularly common topic in the interviews. Each municipality reported several activities that mostly focused on encouraging input from residents about the municipality's future. The meetings are conducted although only a few residents turn up. At other times, several hundred residents turn up. Our material does not involve categorising. We have instead chosen to examine individual examples that are selected to represent what is happening. Participation in budgeting decision-making in Melbourne City might be an interesting example.

The following story is told by the financial director:

It is a requirement of the Local Government Act 1989, section 223, that councils allow members of the public to make submissions to, and be heard by, council committees. Section 129 has details about the nature of the public notice. This applies to many matters like town planning issues that go before planning committees, and budgets and council plans. 
In the City of Melbourne, the Finance and Corporate Performance Committee (FC) deliberates on the annual plan and the annual budget. Public submissions are invited in response to the proposed annual plan and budget in accordance with section 223.

The City of Melbourne (MCC) advertises in the local papers that the budget and plans are available for inspection and comment and submissions and states deadlines for written responses and when the committee will be meeting about them to look at submissions, hear the respondents and deliberate.

Hard copies of budget papers are placed at libraries, city offices, sports centres and such venues. People can also request a hard copy or a PDF.

When a person/group responds with comment, it goes to the Governance section at MCC. They have to 'make sense of the submission', identify the point of contact at MCC who deals with that area, distribute the submission to that area and follow up to make sure that section responds to the submission. The submission and the officer's response are packaged for consideration by the committee. If they desire, those who made a submission may speak before the FC for 3 minutes. The FC makes a decision which goes to meeting of full Council for ratification.

Example: bunch of residents are upset that that no Council \$ allocated in budget to support a local toy library. Submission sent by Governance to Community Services branch (CS). CS manager replies (that toy library had seed funding in the past 2 years and now time to concentrate on other projects that benefit children - so don't recommend any change). Reply and original submission go to FC. Toy library submission people indicate that they wish to be heard. The FC hears them for 3 minutes (maximum) and decides to allocate $\$ 1,000$ to toy library for one more year. That decision goes to full Council meeting for ratification.

Apparently not many people turn up to make suggestions. Only six people had suggestions for the 20052006 budget. These people did however have many sub-propositions. The administration consistently takes them seriously. The director of finance had the impression that interest in the process increased every year.

This is merely one example; every municipality would be able to relate several.

\section{Sweden}

\section{The financial crisis}

Sweden and Victoria were facing the same situation at the outset of the story. There was a financial crisis. The Swedish Central Bank's interest rate was 500\% during a weekend in the Fall of 1992. At the peak of the financial crisis in the 1990s the Swedish government appointed the so called Lindbeck Commission. It consisted of well-known economists, political scientists and others and it was to find a solution for how Sweden might be able to turn the situation around. They quickly delivered their solution (SOU 1993) and had thereby completed their mission. The task was apparently interesting because some members of the Commission, now called the Finance Commission, continued to deliver suggestions for how Sweden might improve.

They wrote the following in their report in 2000:

In addition, establish an agency for municipal auditing which shall be responsible for supervising municipal auditing and which shall also be responsible for evaluating the efficiency of municipal operations. (Lindbeck, et al. 2000 p. 162).

Does this quote not appear somewhat similar to the English Audit Commission? Similar ideas may be found in another official investigation (SOU 2001:76) which is called "Good Financial Management in Municipalities and County Councils" which suggests that the government establish: 
... a national council for municipal finances. This council shall follow and analyse the development of municipal finances. In addition, it shall serve as discussion partner and advisor to municipalities and county councils in need of expert help to analyse their financial situation primarily in cases in which the national government might be expected to play a part (SOU 2001:76 p. 20).

They also suggest that

The auditors shall determine whether the political majority has reached the financial objectives. Not balancing the budget during a four year period might result in consequences regarding granting discharge (SOU 2001:76 p. 18).

A range of inquiries regarding various kinds of municipal auditing subsequently followed. Finding a form that combines municipal independence with uniform oversight has, however, proven difficult. One inquiry is currently trying to find a solution that includes independent municipal auditing.

The idea of comparing key numbers is not new. Swedish municipalities used them as early as the 1930s (Bergevärn and Olson 1987). The issue has received more attention lately; one example includes the Swedish Association of Local Authorities and Regions' so called Key Number Project. In SOU (SOU 2001:75) the person responsible for the inquiry suggests the following:

I suggest 157 indicators for child care, school, health care and elderly care, disability care and family care. These should be divided into 65 performace indicators, 47 financial indicators and 43 key quality indicators (SOU 2001:75 p. 44).

However, other aspects need to be introduced in addition to indicators. The inquiry also suggests... ... as a support for municipalities, one or more contracts should be negotiated for conducting surveys according to the model that the Statistics Sweden has developed for this inquiry and which the municipalities might use (SOU 2001:75 p. 44).

The inquiry also states that:

The organisation that will be responsible for the municipal data base should also be responsible for conducting and publishing cross-sectional analyses as well as for initiating and managing a data bank in which benchmark projects are published and made accessible (SOU 2001:75 p. 61).

Extensive efforts are currently being made to develop useful key numbers. One example includes the creation of the Council for Municipal Analyses and Comparisons (RKA). The RKA was the result of the cooperation between the Swedish government and the Swedish Association of Local Authorities and Regions (SOU 2005:110).

It is always difficult to determine what constitutes cause and effect. However, the person in charge of the inquiry was at the time the director of municipal operations for a large Swedish municipality and is now the director of the Swedish Association of Local Authorities and Regions.

\section{A New Government}

A new Swedish government was elected in 2006. Prior to the election it was clear about what was to be expected based on the belief that there are large problems with the social services, health care and education that are provided by municipalities today. The new government's program contains the following key words: more resources, more choices, open comparisons of the quality of health care units and housing for the elderly. In addition, an independent oversight agency is to be established as will an action plan for measuring quality and ranking units within the public health care system. Alternative management forms for services that are currently provided by the municipalities are also to be encouraged. The national government is clearly demonstrating its power over the municipalities. The program contains much of what the Kennett government did in Victoria in the 1990s.

The various systems for grading students in schools are currently being sharply criticised. The new Minister of Education has stated that he will take action to institute national standardised testing that 
will determine the criteria for grades. In addition, he intends to increase the number government inspections of schools. The National Board for Health and Social Services is inspecting the public health care system more systematically than ever and has subsequently provided sharp and vociferous criticism and more might be expected. While there are more of these types of actions than previously, they are not a recent phenomenon.

\section{Community Engagement and Participant Budgeting}

Our interviews in Swedish municipalities also came to include community engagement. We discovered a range of projects that aimed at encouraging residents' involvement in various issues. Similar activities have existed for a long time, but now appear to have intensified (Gilljam and Jodal 2005). One sign is that the Swedish Association of Local Authorities and Regions, which is the normative organisation in this area, initiated a project which included inviting all Swedish municipalities to participate in a network to discuss community engagement. Over 100 municipalities signed up immediately.

We would like to highlight the case of the municipality of Vara. It is not yet particularly famous for its work in community engagement. A financial director and a mayor told us the following story:

Vara is a median-sized municipality. It has become well known for many different things over the years. It was among the first to introduce financial management with responsibilities. A few years ago the municipality's leadership headed by a so called strong mayor believed that the employees had done a very good job. The employees, about 1000 in all, were rewarded with a trip to the Mediterranean for professional development. Although the municipality is not large, a concert auditorium, which even many larger municipalities don't have, was recently inaugurated. The municipal leadership in particular is involved in many international exchanges. Examples include China, African countries and several European countries.

For many years the municipal leadership regularly visits the smaller communities within its borders so that residents can make suggestions. These meetings have their own budget and decisions can therefore be made quickly. They are currently in the process of developing an additional step regarding community engagement. It is the result partly of the local visits and partly of a visit to Portugal where participant budgeting is commonly used.

The Portuguese example is actually based on the municipality of Porto Allegro in Brazil. (Allegretti and Herzberg 2004).

\section{A Disorganised Order}

The reforms are not particularly organised. The municipal transformation does not follow the path from traditional public management to NPM and subsequently on to something different. Our research instead reveals an interesting disorganisation in which all stages are represented and in which progress may be described as going in any direction at once.

Our material encourages discussions about many areas of reform. One might be tempted to engage in an in-depth discussion about the ways in which reforms tend to propagate in reverse. Municipalities in Victoria appear to be where Swedish municipalities were 10 years ago. Sweden, on the other hand, appears to be where Victoria was 15 years ago. A discussion might also involve the difference between talk and action of two cases. A lot of talk and little action (Sweden) might be contrasted with little talk and much action (Victoria). We have, however, chosen to highlight the relationship between the transformations of old ideas and discuss what factors cause them to become reactivated. In our view, one distinct characteristic is that while most of the things that happen in the organisations that we studied have existed for a long time, they suddenly become very popular. One explanation might include the idea that organisations forget and new reforms are only new to the ones who evaluate the ideas at that particular time. Both Salvador Carmona with German Perez-Casanova (Carmona and PerezCasanova 1993) as well as Karin Brunsson (Brunsson 1998) show evidence that forgetting is prevalent. 
Other writers believe that organisations rather tend to store ideas that they do not currently use (Røvik 1996). Which ideas are actually stored remains unclear as long as they are not needed. Kjell-Arne Røvik believes that the ability to store and use ideas is an important characteristic of modern organisations (Røvik 2000). Albert Danielsson (Danielsson 1983) uses a different metaphor. He claims that old solutions to organisational problems leave some residue which he calls sediment. According to Danielsson, old solutions thus become part of new ones. Nils Brunsson (1997) takes this line of reasoning a step further and maintains that the diffusion theory fails to explain why everyone does not take the same action when faced with the same problem. He claims that reforms, like mushrooms, seem to pop up anywhere, apparently at random. The mushroom metaphor is probably incorrect as any experienced mushroom picker knows approximately where the mushrooms are. The reason why mushroom pickers do not know exactly where the mushrooms grow is that they are not familiar with the exact conditions for wild mushrooms. It might be different if they try to grow mushrooms, but the analogy is not the same. Nils Brunsson' discussion about why reforms happen touches upon the fact that while we might never be able to fully understand why, we will be able to understand more and more.

None of the reforms we saw in Victoria or in Sweden are new. They have all existed, to some extent, in each individual municipality. There are instead various combinations of small ideas becoming large and vice versa.

To understand the various combinations we return to Tarde's (1890/1962) belief that ideas need to be logically superior and reasonable. This means that an idea that has worked on a smaller scale will subsequently be used more. Proven ideas might also be less likely to interfere with ideas that are already institutionalised. The latter contains some sediment from the old ideas. Allonymism may thus be viewed as very common and might even be the most common aspect of new reforms. However, it appears more reasonable to adapt Tarde's view that Fashion Centers control transformation and view them instead as catalysts. We have thus only observed aspects of what Tarde refers to as imitating habits. An idea that is presented as new is more likely to be accepted if it contains a sufficient number of familiar components. According to this view, reforms, and particularly their individual components, are the subject of continuous recycling which are actually merely new combinations. The reforms' sustainability is thus high. There are many ways to sauté mushroom, and which one is best is a question of negotiation.

\section{References}

Allegretti, G. and Herzberg, C. 2004. Participatory budgets in Europe: between efficiency and growing local democracy. TNI briefing series 2004/5. Amsterdam: Transnational Institute.

Barley, S. and Tolbert, P. 1997. "Institutionalization and structuration: studying the links between action and institution", Organization Studies. 18:(1): 93.

Bergevärn, L.E. and Olson, O. 1987. Kommunal redovisning då och nu : längtan efter likformighet, rättvisa och affärsmässighet. Lund: Doxa.

Bourdieu, P. 1990. The logic of practice. Cambridge: Polity.

Brunsson, K. 1998. "Non-learning organizations”, Scandinavian Journal of Management. 14:(4): 421432.

Brunsson, N. 1997. "The standardization of organizational forms as a cropping-up process", Scandinavian Journal of Management. 13:(3): 307-320.

Brunsson, N. 2000. The irrational organization: irrationality as a basis for organizational action and change. Bergen: Fagbokforl.

Callon, M., 1986. "Some elements of a sociology of translation: domestication of the scallops and fishermen of St Brieuc Bay", in Law, J. (ed.), Power, action and belief. London: Kegan Pauö.

Carmona, S., and Perez-Casanova, G. 1993. "Organizational forgetting and information systems", Scandinavian Journal of Management. 9:(1): 29-44.

Czarniawska, B. 2005. "Fashion in organizing", in Czarniawka, B. and Sevòn, G. (eds.), Global ideas. Lund: Liber. 
Czarniawska, B. and Joerges, B. 1995. "Winds of organizational change: how ideas translate into objects and actions", in Bacharach, S., Gagliardi P., and Mundell B. (eds.), Research in sociology of organizations. Greenwich: JAI Press.

Czarniawska, B. 2001. "Is it possible to be a constructionist consultant?", Management Learning. 32:(2): 253-266.

Danielsson, A. 1983. Företagsekonomi - en översikt. Lund: Studentlitt.

Danziger, James N., 1978. Making budgets: public resource allocation. Beverly Hills: Sage.

DiMaggio, P. 1983. "State expansion in organizational fields", in Hall, R. and Quinn, R. (eds.), Organizational theory and public policy. Beverly Hills, CA: Sage.

Gerritsen, R. and Whyard, M. 1998. "The Challenge of constant change: the Australian local government CEO", in Klausen, K. and Magnier, A. (eds.), The Anonymous Leader: Appointed CEOs in Western Local Government. Odense: Odense University Press.

Gilljam, M. and Jodal, O. 2005. Demokratiutveckling i svenska kommuner: D3 - Kommunala demokratisatsningar - vägen till en mer vital demokrati? Göteborg: Centrum för forskning om offentlig sektor (CEFOS), Göteborgs Universitet.

Hofstede, G., 1991. Cultures and organizations: software of the mind. New York: McGraw-Hill.

Hood, C., 1991. “A public management for all seasons?”, Public Administration. 69:(1): 3-19.

Jönsson, S., 1982. A city administration facing stagnation: political organization and action in Gothenburg. Stockholm: Swedish council for building research Statens råd för byggnadsforskning Sv. byggtjänst (distr.).

Jönsson, S., Rubenowitz, S. and Westerståhl, J. 1995. Decentralized city: the example Göteborg. Göteborg. BAS.

Kreiner, K. and Mouritsen, J. 2005. "The analytical interview: relevance beyond reflexivity", in Tengblad, S., Solli R. and Czarniawska, B. (eds.), The art of science. Malmö: Liber.

Latour, B. 1986. "The powers of association", in John Law (ed.), Power, action and belief. London: Kegan Paul.

Latour, B. 1994. "Preface to power", in Power, M. (ed.), Accounting and Science. Cambridge: Cambridge University Press, xi-xvii.

Lindbeck, A., Molander, P., Persson, T., Petersson, O. and Swedenborg, B. 2000. Ekonomirådets rapport 2000: politisk makt med oklart ansvar. Stockholm: Studieförb. Näringsliv och samhälle.

Mintzberg, Henry, 1978. "Patterns in strategy formation", Management Science. 24:(9): 934-948.

Mintzberg, H. (1994). "The fall and rise of strategic planning". Harvard Business Review, January-February: 107-114.

Parkinson, T. 2000. Jeff - the rise and fall of a political phenomenon. Melbourne: Viking.

Powell, W.. and DiMaggio, P. 1991. The new institutionalism in organizational analysis. Chicago: University of Chicago Press.

Røvik, K-A. 1996. "Deinstitutionalization and logic of fashion", in Czarniawka, B. and Sevòn, G. (eds.), Translating Organizational Change. Berlin: de Gruyter.

Røvik, K-A. 2000. Moderna organisationer: trender inom organisationstänkandet vid millennieskiftet. Malmö: Liber.

Sahlin-Andersson, Kerstin, 2001. "National, international and transnational constructions of New Public Management", in Christensen, T. and Lægreid, P. (eds), New Public Management - The transformations of ideas and practice. Ashgate: Aldershot.

Solli, R. 1988. Decentralisering i kommuner : om politik och administration på lokal nivå. Lund: Studentlitteratur.

Solli, R., Demediuk, P. and Sims, R. 2000. Chief Finance Officers in local government - Sweden vs Australia. Göteborg: School of Public Administration, Göteborg University.

Solli, R., Demediuk, P. and Sims, R. 2005. "The Namesake - on Best Value and other reformmarks", in Czarniawska, B. and Sevón (eds.), How ideas, objects and practices travel in the global economy. Malmö \& Köpenhamn: Liber.

SOU. 1993. Nya villkor för ekonomi och politik- Ekonomikommissionens förslag : betänkande. Stockholm: Allmänna förlaget. 
SOU. 2001. Betänkande från Utredningen för en fortsatt ut-veckling av en kommunal databas. Stockholm: Finansdepartementet.

SOU. 2001. God ekonomisk hushållning $i$ kommuner och landsting - Betänkande från Ekonomiförvaltningsutredningen. Stockholm: Finansdepartementet.

SOU. 2005. Jämförelsevis. Styrning och uppföljning med nyckeltal $i$ kommuner och landsting. Stockholm: Finansdepartementet.

Tarde, G. 1890/1962. The laws of imitation . Glocester, MA: Peter Smith

Trompenaars, F. and Hampden-Turner, C. 2005. Riding the waves of culture: understanding cultural diversity in business. London: Nicholas Brealey.

Van Gunsteren, H. 1976. The quest for control: a critique of the rational-central-rule approach in public affairs. London: Wiley.

Wildavsky, A. 1975. Budgeting: a comparative theory of budgetary processes. Boston: Little Brown and Co.

Whittington, R. 2004. "Strategy after modernism: recovering practice", European Management Review. 1: (1): 62-68. 